\title{
PENGARUH MODEL PEMBELAJARAN PROBING PROMPTING BERBANTUAN VIDEO TERHADAP HASIL BELAJAR DAN KEMAMPUAN BERPIKIR KRITIS PESERTA DIDIK
}

\author{
Rosi Pratiwi, Hikmawati*, I Wayan Gunada \\ Program Studi Pendidikan Fisika, Universitas Mataram \\ *Email : hikmawati@unram.ac.id
}

DOI: http://dx.doi.org/10.29303/jpft.v5i2.1207

\begin{abstract}
This research aim to examine the effect of probing prompting assisted video learning model for learning outcomes and critical thinking skill of student. This type of research is quasi experiment with untreated control group design with pretest and posttest. The research population was all students of X MIA MAN 2 Mataram. Sampling technique of this research use cluster random sampling so that there are two classes that is X MIA 1 as the experimental class and X MIA 3 as the control class. Type test used 20 choice question for learning outcomes and 5 essay for critical thinking skill. The posttest mean value for learning outcomes in experimental class and control class is 42,36 and 34,86. The posttest mean value for critical thinking skill in experimental class and control class is 54,86 and 46,08. Hypothesis testing of this research is MANOVA. The result of MANOVA test show a significant 0,004 so $H_{0}$ is rejected and $H_{a}$ is accepted. The conclusion of this research is there is the effect of probing prompting learning model assisted video for learning outcomes and critical thinking skill of student.
\end{abstract}

Keywords: probing prompting; learning outcomes; critical thinking

\section{PENDAHULUAN}

Pembelajaran abad 21 menekankan pada peningkatan kualitas SDM melalui bidang pendidikan yang difokuskan pada kemampuan berpikir tingkat tinggi (HOTS). HOTS merupakan salah satu kemampuan yang dibutuhkan untuk mempersiapkan lulusan yang mampu bersaing dan beradaptasi dengan perubahan zaman. Berpikir kritis merupakan salah satu kemampuan berpikir tingkat tinggi (Sari dan Sugiyanto, 2015). Menurut Ennis (2011) berpikir kritis adalah pemikiran yang masuk akal dan reflektif yang berfokus pada penentuan apa yang harus dipercaya atau dilakukan, sehingga diperlukan latihan, tidak hanya sekedar menghafal konsep karena proses pembelajaran adalah memanfaatkan potensi otak (Fathurrohman, 2015).

Handriani et al (2015) menyatakan bahwa kemampuan berpikir kritis adalah suatu proses kognisi peseta didik secara mendalam yang diterapkan dalam kegiatan pembelajaran yang memenuhi beberapa indikator. Pengembangan kemampuan berpikir kritis menjadi sangat penting bagi peserta didik agar memperoleh hasil yang optimal. Penyebab kurang mampu meningkatkan kemampuan berpikir kritis adalah model pembelajaran yang digunakan dalam pembelajaran terkesan monoton dan kurang variatif. Pembelajaran fisika seharusnya mempertimbangkan strategi atau metode pembelajaran yang efektif dan efesien dalam meningkatkan hasil belajar dan kemampuan berpikir kritis peserta didik.

Abad 21 juga dikenal dengan masa pengetahuan. Pengetahuan diperoleh melalui pendidikan. Percepatan peningkatan pengetahuan ini didukung oleh penerapan media dan teknologi digital. Pemanfaatan media pembelajaran dapat mempermudah dalam penyampaian materi dengan memberikan gambaran terhadap sesuatu yang abstrak. Media pembelajaran yang dikemas secara apik sesuai dengan kebutuhan akan memberikan dampak yang positif ketika pembelajaran berlangsung. Beberapa manfaat penggunaan media pembelajaran yaitu : penyajian lebih baku, 
menarik, interaktif, dan efisien (Arsyad, 2002).

Video merupakan salah satu media yang dapat digunakan dalam pembelajaran. Media pembelajaran video merupakan faktor eksternal yang instrumental yaitu sebagai sarana atau fasilitas. Faktor eksternal juga sangat berpengaruh, misalkan pada aspek fisiologis dan psikologis. Peserta didik terkadang termotivasi namun juga dapat mengalami kejenuhan dalam penyimakannya, terlepas dari itu, media video telah terbukti memiliki kemampuan yang efektif untuk menyampaikan informasi, hiburan, dan pendidikan (Warsita, 2008). Penggunaan video dalam pembelajaran dapat membantu guru dalam memberikan masalah-masalah nyata di dalam kelas. Penggunaan video dengan maksimal dapat mendukung suatu bentuk pembelajaran berdasarkan permasalahan dalam kehdupan sehai-hari dan mampu memberikan kemudahan untuk menganalisis, memberikan bukti, dan mengambil kesimpulan dari permasalahan yang diberikan. Pembelajaran menggunakan video dapat membuat belajar fisika lebih menarik, interaktif, dan komunikatif yang lebih menekankan pada proses pembentukan pengetahuan secara aktif serta mampu memfokuskan perhatian peserta didik selama proses belajar (Resta, 2013).

Hasil observasi yang dilakukan di MAN 2 Mataram pada tanggal 22 September 2018 adalah pembelajaran fisika masih berpusat pada guru dan peserta didik hanya mendengarkan. Guru menyampaikan materi dan hanya berinteraksi dengan peserta didik ketika meminta mereka untuk bertanya atau menjawab soal di papan tulis. Pembelajaran yang masih berfokus pada guru dan melibatkan peserta didik hanya ketika menjawab soal menyebabkan peserta didik kurang aktif dalam pembelajaran dan kurang mengembangkan kemampuan berpikirnya. Pembelajaran fisika di MAN 2 Mataram lebih difokuskan pada penyampaian rumusrumus untuk menyelesaikan soal-soal di buku dan jarang memberikan contoh nyata penerapannya dalam kehidupan sehai-hari sehingga peserta didik mengalami kesulitan dalam mengembangkan konsep fisika. Peserta didik lebih memilih menghafal rumus dibandingkan memahami konsep sehingga sulit menjawab ketika diberikan soal yang lebih sulit dikarenakan susah menganalisis soal tersebut. Penggunaan media dalam menunjang pembelajaran juga jarang digunakan walaupun LCD sudah terpasang di setiap kelas. Hal ini didapatkan dengan melakukan pengamatan ketika guru sedang mengajar di kelas dan wawancara dengan peserta didik.

Menurut Nurmayani et al. (2018) setelah melakukan observasi dan tes awal yang diberikan, proses pembelajaran yang berlangsung selama ini belum mampu meningkatkan kemampuan berpikir kritis karena aspek kognitif hanya menekankan pada hasil dan bukan pada aspek proses yang melibatkan kemampuan berpikir kritis. Septiana et al. (2018) mengungkapkan bahwa proses pembelajaran yang bersifat teacher center tidak memberikan akses bagi peserta didik untuk berkembang secara mandiri dalam menemukan sendiri pengetahuannya sehingga berdampak pada kemampuan berpikir tingkat tinggi terutama pada kemampuan berpikir kritis yang rendah. Penyebab hal tersebut adalah peserta didik tidak pernah dilatih untuk berpikir kritis dalam pembelajaran serta aspek kognitif hanya dalam bentuk teori dan hafalan.

Permasalahan di atas dapat diatasi dengan lebih inovatif dalam mengembangkan model pembelajaran yang dapat meningkatkan hasil belajar dan kemampuan berpikir kritis peserta didik. Salah satu model pembelajaran yang dapat meningkatkan hasil belajar dan kemampuan berpikir kritis peserta didik yaitu model 
pembelajaran probing prompting. Probing prompting adalah suatu model pembelajaran yang berpusat pada peserta didik. Model pembelajaran ini sesuai dengan paham konstruktivis yang memberikan keluasan pada peserta didik untuk aktif mengkonstruksi pengetahuan sendiri. Model pembelajaran probing prompting dapat dibantu dengan menggunakan video. Penggunaan media video adalah untuk memusatkan perhatian peserta didik dan memberikan situasi baru yang akan menjadi landasan bagi peserta didik untuk merumuskan permasalahan serta sebagai landasan bagu guru dalam membuat pertanyaan.

Probing adalah penyelidikan dan pemeriksaan, sementara prompting adalah mendorong atau menuntun. Pembelajaran probing prompting adalah pembelajaran dengan menyajikan serangkaian pertanyaan yang sifatnya menuntun dan menggali gagasan peserta didik sehingga dapat meningkatkan proses berpikir peserta didik. Pembelajaran dengan menggunakan model probing prompting dapat memotivasi peserta didik untuk memahami masalah dengan lebih mendalam sehingga peserta didik mampu mencapai jawaban yang diinginkan. Jawaban atas pertanyaan yang diajukan didapatkan dengan menghubungkan pengetahuan dan pengalaman yang telah dimiliki peserta didik (Huda, 2017). Rahmadi (2016) menyatakan bahwa penerapan model probing prompting dalam pembelajaran dapat meningkatkan kemampuan berpikir kritis peserta didik yang dibuktikan dengan meningkatnya hasil belajar kognitif peserta didik.

Penelitian sebelumnya yang menerapkan model pembelajaran probing prompting, diantaranya yaitu Isna et al. (2014) dan Sahayu et al. (2018) menyatakan bahwa model pembelajaran probing prompting dapat meningkatkan hasil belajar peserta didik. Penelitian tersebut menerapkan model pembelajaran probing prompting berbantuan media power point dan alat peraga. Penelitian lainnya menerapkan penggunaan media video dalam pembelajaran diantaranya Diani et al. (2016) dan Endriani et al. (2018) menyatakan bahwa pembelajaran berbantuan video juga dapat meningkatkan hasil belajar dan kemampuan berpikir kritis peserta didik. Penelitian-penelitian di atas mendorong peneliti untuk melakukan penelitian menggunakan model pembelajaran probing prompting berbantuan video untuk meningkatkan hasil belajar dan kemampuan berpikir kritis peserta didik.

\section{METODE PENELITIAN}

Penelitian ini merupakan penelitian kuasi eksperimen, dengan desain penelitian, yaitu untreated control group design with pretest and posttest. Proses pembelajaran menggunakan model pembelajaran probing prompting berbantuan video pada kelas eksperimen dan model pembelajaran konvensional pada kelas kontrol. Instrumen tes hasil belajar menggunakan tes pilihan ganda dengan jumlah soal 20 dan instrumen tes kemampuan berpikir kritis menggunakan tes essay dengan jumlah soal 5 pada materi getaran harmonis dengan subjek penelitian adalah peserta didik kelas X MIA di MAN 2 Mataram. Kelas X MIA 1 dipilih sebagai kelas eksperimen dan kelas X MIA 3 sebagai kelas kontrol dengan teknik cluster random sampling.

Data hasil belajar dan kemampuan berpikir kritis diuji prasyarat, berupa uji homogenitas dan uji normalitas. Kemudian dilanjutkan dengan uji hipotesis menggunakan uji MANOVA. Data hasil belajar dan kemampuan berpikir kritis diuji dengan menggunakan uji $\mathrm{N}$-gain secara lebih lanjut untuk mengetahui peningkatan per indikator. 
HASIL DAN PEMBAHASAN

Penelitian ini dilaksanakan di MAN 2 Mataram dengan menerapkan model pembelajaran probing promprting berbantuan video, yaitu model pembelajaran dimana guru menyajikan serangkaian pertanyaan yang sifatnya menuntun dan menggali sehingga terjadi proses berpikir yang mengaitkan pengetahuan tiap peserta didik dan pengalamannya dengan pengetahuan baru yang sedang dipelajari yang kemudian peserta didik akan mengkonstruksi konsepnya menjadi pengetahuan baru. Penelitian ini menggunakan dua kelompok sampel yaitu kelas eksperimen dan kelas kontrol yang bertujuan untuk mengetahui pengaruh model pembelajaran probing prompting berbantuan video terhadap hasil belajar dan kemampuan berpikir kritis peserta didik.

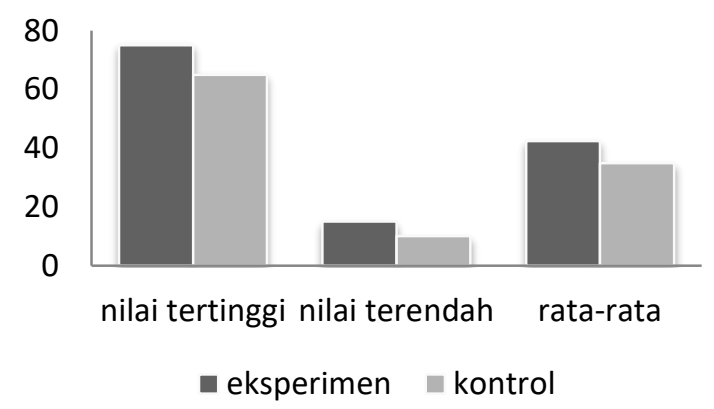

Gambar 2. Grafik Data Tes Akhir Hasil Belajar

Hasil belajar yang diukur dalam penelitian ini yaitu hasil belajar dalam ranah kognitif dengan indikator C1 sampai C6. Data mengenai hasil belajar peserta didik sebelum dan sesudah diberikan perlakuan dapat dilihat melalui tes awal (pretest) dan tes akhir (posttest). Hasil belajar peserta didik untuk kelas eksperimen dan kelas kontrol sebelum diberikan perlakuan sangat rendah bahkan nilai tertinggi tidak ada yang mencapai rata-rata yaitu 40 untuk kelas eksperimen dan 35 untuk kelas kontrol. Nilai yang rendah untuk kelas eksperimen dan kelas kontrol pada tes awal disebabkan karena kedua kelas belum diberikan perlakuan dan belum diajarkan mengenai materi getaran harmonis.

Tes akhir (posttest) diberikan pada kelas eksperimen dan kelas kontrol setelah diberikan perlakuan. Tes akhir (posttest) diberikan untuk mengetahui apakah ada pengaruh atas perlakuan yang sudah diberikan untuk materi getaran harmonis. Tes akhir (posttest) yang diberikan jumlah dan bobot soalnya sama dengan tes awal (pretest). Hasil yang diperoleh untuk kelas eksperimen setelah diberikan tes akhir (posttest) yaitu nilai rata-ratanya lebih tinggi dibandingkan kelas kontrol yaitu 42,36 untuk kelas eksperimen dan 34,86 untuk kelas kontrol. Nilai tertinggi dan nilai terendah untuk kelas eksperimen lebih tinggi dibandingkan kelas kontrol yaitu 75 untuk nilai tertinggi sedangkan 15 untuk nilai terendah pada kelas eksperimen dan 65 untuk nilai tertinggi sedangkan 10 untuk nilai terendah untuk kelas kontrol.

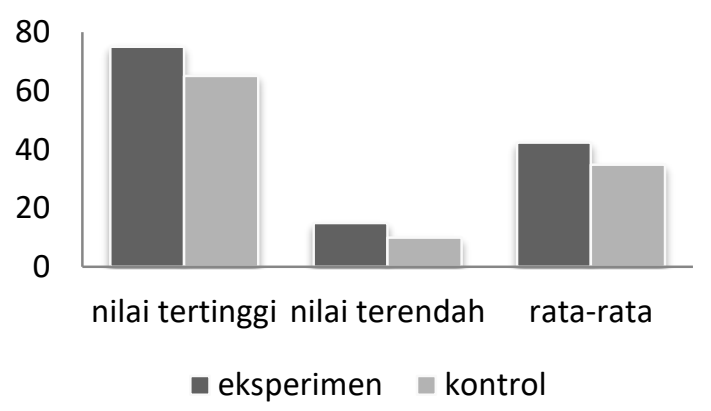

Gambar 2. Grafik Data Tes Akhir Hasil Belajar

Kemampuan berpikir kritis diukur melalui proses dan tes akhir. Kemampuan berpikir kritis pada saat proses pembelajaran dilihat dari kegiatan pembelajaran dimulai dari merumuskan permasalahan berdasarkan video yang ditampilkan hingga saat peserta didik menjawab pertanyaan dari pengajar. Kemampuan berpikir kritis diukur pada saat proses pembelajaran dengan tujuan untuk melihat bagaimana peningkatan kemampuan berpikir kritis untuk kedua kelas di setiap pertemuan. Indikator kemampuan berpikir kritis khususnya klasifikasi dasar pada saat 
proses pebelajaran berada dalam kategori lemah untuk kedua kelas. Penyebab indikator klasifikasi dasar lemah karena peserta didik kurang memahami bagaimana cara merumuskan permasalahan pada saat pembelajaran. Indikator kemampuan berpikir kritis yang paling tinggi pada saat proses pembelajaran yaitu penjelasan lebih lanjut untuk kedua kelas. Indikator penjelasan lebih lanjut memiliki nilai paling tinggi dikarenakan pada saat pemberian pertanyaan, peserta didik sudah mencari informasi lebih dulu dari buku dan percobaan. Kemampuan berpikir kritis peserta didik selama proses pembelajaran masih dalam kategori kurang kritis tetapi terdapat peningkatan disetiap pertemuan. Penyebab masih rendahnya kemampuan berpikir kritis peserta didik selama proses pembelajaran yaitu ketika pembelajaran masih ada campur tangan guru. Guru banyak membantu peserta didik dari merumuskan permasalahan hingga menarik kesimpulan khususnya pada kelas kontrol. Kelas eksperimen mengalami peningkatan kemampuan berpikir kritis yang lebih tinggi dibandingkan kelas kontrol untuk setiap pertemuan.

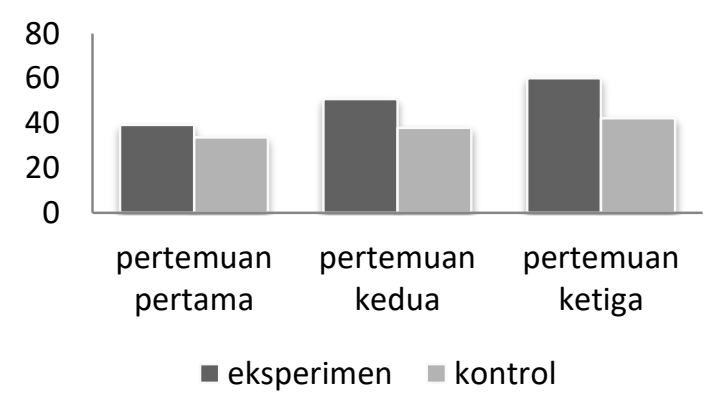

Gambar 4.7 Nilai Rata-Rata Tingkat Kemampuan Berpikir Kritis Melalui LKPD Perbedaan kemampuan berpikir kritis di kelas kontrol dan kelas eksperimen pada saat pembelajaran yaitu peserta didik lebih aktif mengemukakan pendapatnya di kelas eksperimen terutama pada kegiatan dimana peneliti mengajukan pertanyaan. Jawaban yang diberikan kelas eksperimen lebih beragam dan lebih tepat dibandingkan kelas kontrol. Perbedaan lainnya yaitu pada saat menarik kesimpulan. Peserta didik pada kelas eksperimen lebih tepat dan lengkap ketika membuat kesimpulan dibandingkan kelas kontrol dimana ada beberapa peserta didik menarik kesimpulan tidak sesuai dengan konteks yang dibahas.

Indikator kemampuan berpikir kritis yang diukur yaitu keputusan dasar, klasifikasi dasar, inferensi, penjelasan lebih lanjut, serta menalar dan pengintegrasian. Kemampuan berpikir kritis peserta didik diukur pada saat tes awal (pretest) untuk mengetahui pengetahuan awal peserta didik sebelum diberikan perlakuan dan di akhir (posttest) untuk melihat peningkatan setelah diberikan perlakuan. Kemampuan berpikir kritis dilihat dengan memberikan soal essay berjumlah 5 soal. Hasil yang diperoleh ketika diberikan tes awal (pretest) yaitu kelas eksperimen dan kelas kontrol memiliki nilai tertinggi yang sama namun nilai terendah untuk kelas kontrol lebih kecil dibandingkan nilai tertinggi untuk kelas eksperimen. Rata-rata nilai kemampuan berpikir kritis untuk kelas eksperimen lebih tinggi daripada kelas kontrol pada saat diberikan tes awal (pretest) yaitu 36,94 untuk kelas eksperimen dan 32,16 untuk kelas kotrol.

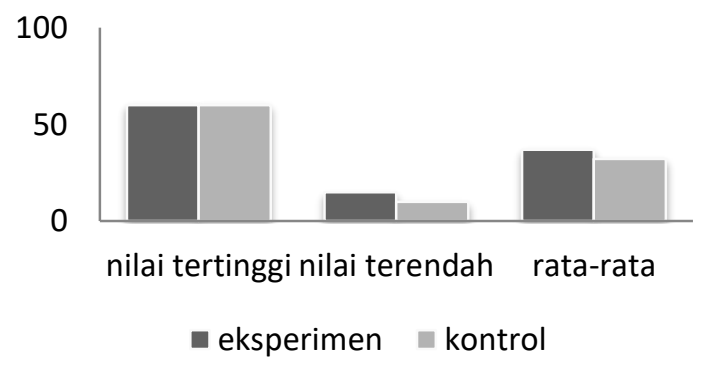

Gambar 4.3 Data Tes Awal Kemampuan Berpikir Kritis

Tes akhir (posttest) diberikan pada kelas eksperimen dan kelas kontrol pada saat selesai diberikan perlakuan. Nilai tertinggi kelas eksperimen lebih tinggi dibandingkan kelas kontrol namun nilai terendah untuk kelas eksperimen dan kelas kontrol besarnya sama yaitu 25. Rata-rata nilai kemampuan 
berpikir kritis kelas eksperimen lebih tinggi dibandingkan kelas kontrol yaitu 54,86 untuk kelas eksperimen dan 46,08 untuk kelas kontrol.

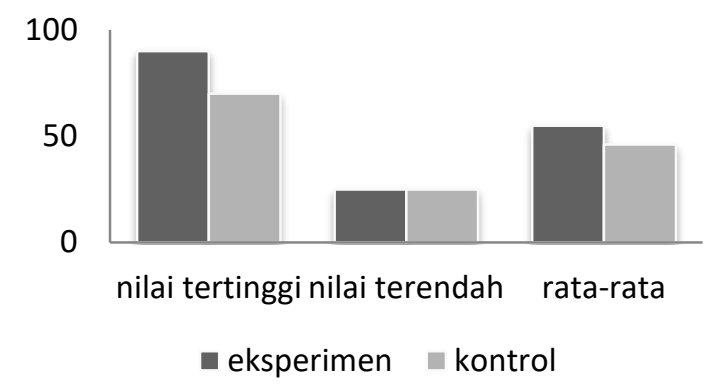

Gambar 4.5 Data Tes Akhir Kemampuan Berpikir Kritis

Peneliti memberikan perlakuan yang berbeda untuk kelas eksperimen dan kelas kontrol ketika mengajar. Kelas eksperimen berjumlah 36 orang diajarkan dengan menggunakan model pembelajaran probing prompting berbantuan video. Kelas kontrol berjumlah 37 orang dajarkan menggunakan model pembelajaran konvensional. Kegiatan pembelajaran di kelas eksperimen diawali dengan menghadapkan peserta didik pada situasi baru yaitu meminta peserta didik untuk memperhatikan video yang diberikan oleh peneliti di depan kelas yang kemudian peneliti meminta peserta didik merumuskan permasalahan dari video yang ditayangkan mengenai getaran harmonis. Peserta didik mencoba menjawab permasalahan yang sebelumnya dirumuskan dengan melakukan percobaan dan mencari informasi dari berbagai sumber seperti buku. Fase selanjutnya yaitu mengajukan pertanyaan dimana peneliti mengajukan pertanyaan mengenai rumusan masalah yang dibuat setelah melihat video kepada peserta didik. Peneliti akan menyebut salah satu nama peserta didik yang kemudian diberikan pertanyaan. Peserta didik menarik kesimpulan atas permasalahan yang dibuat pada akhir pembelajaran.

Model pembelajaran probing prompting erat kaitannya dengan pemberian pertanyaan sehingga peserta didik lebih aktif dan mudah mengingat konsep pada materi getaran harmonis. Kegiatan pembelajaran selama fase mengajukan pertanyaan, peserta didik terlihat antusias dan perhatiannya terpusat pada pengajar. Model pembelajaran probing prompting dibantu dengan menampilkan video di awal pembelajaran sehingga perhatian peserta didik sudah difokuskan dari awal pembelajaran. Peserta didik dapat lebih mudah memahami dan mengingat konsep pada materi getaran harmonis karena melalui model pembelajaran ini peserta didik dituntut berpikir mengenai suatu permasalahan dan menciptakan suasana pembelajaran seperti diskusi dimana peserta didik dapat menanggapi jawaban dari temannya.

Uji hipotesis menggunakan uji MANOVA yaitu untuk mengetahui pengaruh model pembelajaran probing prompting berbantuan video terhadap hasil belajar dan kemampuan berpikir kritis secara bersama-sama. Uji MANOVA memiliki dua syarat yaitu uji Box'M dan uji Levene's. Uji Box'M dan uji Levene's harus terpenuhi sehingga uji manova bisa dilanjutkan. Data yang digunakan dalam uji hipotesis yaitu data tes akhir (posttest). Nilai signifikan yang didapatkan pada saat uji box dan uji levene's lebih besar dari 0,05 sehingga uji manova dapat dilanjutkan. Berdasarkan uji manova yang telah dilakukan, didapatkan signifikannya lebih kecil dari 0,05 sehingga dapat disimpulkan bahwa ada pengaruh model pembelajaran probing prompting berbantuan video terhadap hasil belajar dan kemampuan berpikir kritis peserta didik.

Peningkatan hasil belajar dan kemampuan berpikir kritis pada tes awal (pretest) dengan tes akhir (posttest) dapat dilihat dengan menggunaan uji $\mathrm{N}$-gain. Hasil uji $\mathrm{N}$-gain untuk hasil belajar yaitu kelas eksperimen mengalami peningkatan yang lebih tinggi dibandingkan kelas kontrol. Peningkatan hasil belajar untuk kelas eksperimen termasuk kedalam kategori 
sedang dan kategori rendah untuk kelas kontrol. Peningkatan hasil belajar tertinggi di kelas eksperimen yaitu pada indikator C6 dan yang terendah yaitu indikator C5. Indikator $\mathrm{C} 1$ mengalami peningkatan lebih tinggi di kelas kontrol dan indikator C5 mengalami peningkatan yang lebih rendah.

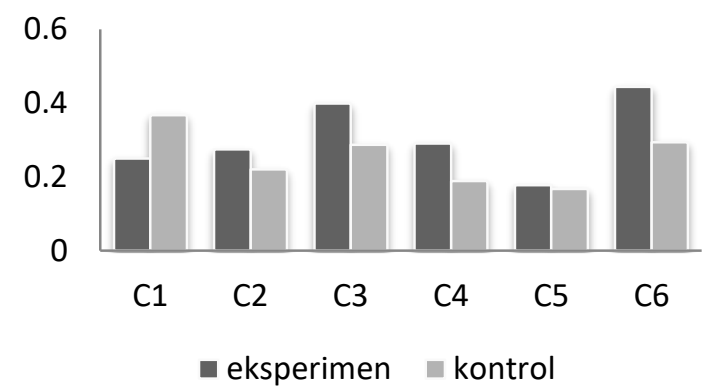

Gambar 3. Peningkatan Hasil Belajar Kelas Eksperimen dan Kelas Kontrol

Berdasarkan uji N-gain didapatkan peningkatan kemampuan berpikir kritis masih rendah pada kelas eksperimen dan kelas kontrol tetapi peningkatan di kelas eksperimen lebih tinggi dibandingkan di kelas kontrol. Peningkatan kemampuan berpikir kritis yang lebih besar pada kelas eksperimen yaitu pada indikator penjelasan lebih lanjut dan yang paling rendah yaitu pada indikator keputusan dasar. Indikator inferensi paling besar di kelas kontrol dan keputusan dasar paling kecil. Indikator keputusan dasar di kelas kontrol memiliki nilai negatif hal ini dapat disebabkan karena ketika menjawab soal, banyak peserta didik yang menjawab secara asal-asalan atau hanya menebak pada saat tes awal dan tes akhir sehingga berdasarkan grafik dapat dilihat bahwa nilai kelas kontrol untuk indikator keputusan dasar mengalami penurunan. Indikator keputusan dasar mengalami penurunan dikarenakan banyak peserta didik di kelas kontrol yang awalnya menjawab benar di tes awal malah menjawab salah pada tes akhir. Peneliti lebih menekankan pada indikator berpikir kritis yang dilihat rendah berdasarkan nilai pretest pada saat proses pembelajaran yang menyebabkan hasil posttest untuk indikator yang awalnya rendah menjadi meningkat sedangkan indikator yang awalnya tinggi pada saat pretest mengalami penurunan bahkan bernilai negatif.

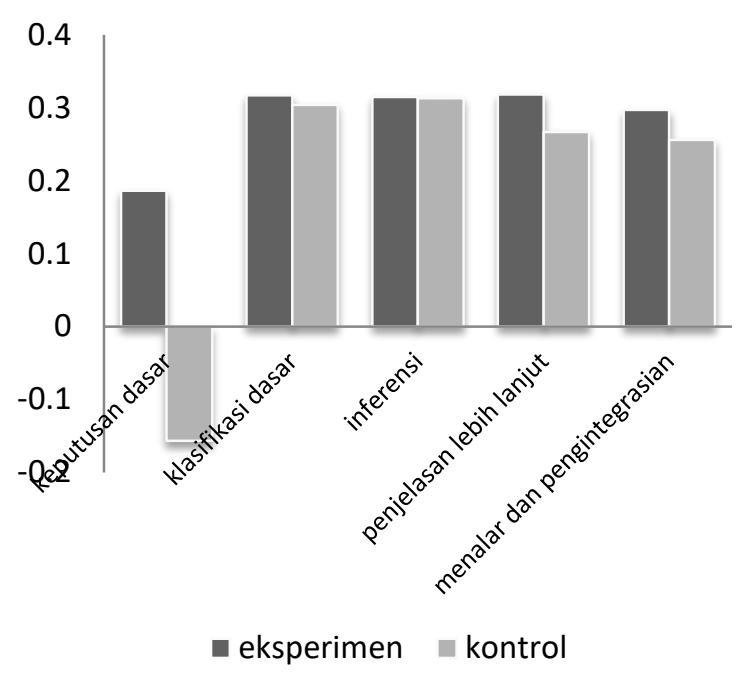

Gambar 4.9 Peningkatan Kemampuan Berpikir Kritis Kelas Eksperimen dan Kelas Kontrol

\section{PENUTUP}

Berdasarkan rumusan masalah, hasil penelitian, dan pembahasan dapat disimpulkan bahwa ada pengaruh model pembelajaran probing prompting berbantuan video terhadap hasil belajar dan kemampuan berpikir kritis peserta didik. Ketika guru atau peneliti lain ingin menerapkan pembelajaran probing prompting di dalam kelas sebaiknya guru atau peneliti memberikan pemahaman kepada peserta didik dalam merumuskan permasalahan agar peserta didik tidak kesulitan dalam merumuskan permasalahan. Penerapan model pembelajaran probing prompting di dalam kelas menuntut guru harus lebih tegas terutama pada fase mengajukan pertanyaan agar pembelajaran berjalan dengan baik. Selama memberikan perlakuan pada kelas kontrol dan kelas eksperimen sebaiknya jangan hanya menekankan kepada beberapa indikator berpikir kritis yang memiliki nilai rendah pada saat pretest. 


\section{REFERENSI}

Arsyad, A. 2002. Media Pembelajaran. Jakarta: Raja Grafindo Persada.

Diani, R., Yuberti., \& Syafitri, S. 2016. Uji Effect Size Model Pembelajaran Scramble dengan Media Video Terhadap Hasil Belajar Fisika Peserta Didik Kelas X MAN 1 Pesisir Barat. Jurnal Ilmiah Pendidikan Fisika Al-Biruni 05(2), 267-277.

Endriani, R., Sundaryono, A., \& Elvia, R. 2018. Pengembangan Media Pembelajaran Kimia Menggunakan Video untuk Mengukur Kemampuan Berpikir Kritis Siswa. Journal of Science Educarion 2(2), 142-146.

Ennis R H. 2011. The Nature of Critical Thinking : An Outline of Critical Thinking Disposition and Abilities. University of Illinos. On line at http://faculty.education.illions.edu/ rhennis/documents/TheNatureofCri ticalThinking 51711_000.pdf.

Fathurrohman, M. 2015. Model-model Pembelajaran Inovatif. Jogjakarta: Ar-Ruzz Media.

Isna, R., Hendratto, S., \& Ristanto S. 2014. Penerapan Model Pembelajaran Probing Prompting Berbantuan Media Power Point pada Materi Mekanika Fluida untuk Meningkatkan Hasil Belajar Siswa Kelas XI IPA 5 SMAN 1 Bae Kudus. Mathematics and Sains Forum.

Handriani, L.S., Harjono, A., \& Doyan, A. 2015. Pengaruh Model Pembelajaran Inkuiri Terstruktur dengan Pendekatan Saintifik Terhadap Kemampuan Berpikir Kritis dan Hasil Belajar Fisika Siswa. Jurnal Pendidikan Fisika dan Teknologi, 1(3), 210-220.

Huda, M. 2017. Model-model Pengajaran dan Pembelajaran : Isu-isu Metodis dan Paragmatis. Yogyakarta: Pustaka Pelajar.
Nurmayani, L., Doyan, A., \& Verawati, N. N. S. P. 2018. Pengaruh Model Pembelajaran Inkuiri Terbimbing Terhadap Kemampuan Berpikir Kritis Peserta Didik. Jurnal Pendidikan Fisika dan Teknologi Vol 4(1) Hal: 98-104.

Sari, D.S \& Sugiyanto, K.H. 2015. Pengembangan Multimedia Berbasis Masalah untuk Meningkatkan Motivasi Belajar dan Kemampuan Berpikir Kritis Siswa. Jurnal Inovasi Pendidikan IPA, 1(2), 154.

Rahmadi, T.N., Maryanto, A., \& Setianingsih, W. 2016. Pengaruh Penerapan Probing Prompting pada Pembelajaran IPA SMP Kelas VII Terhadap Kemampuan Berpikir Kritis Siswa. Jurnal Pendidikan Matematika dan Sains, 5(4), 1-9.

Resta, L., I., Fauzi, A \& Yulkifli. 2013. Pengaruh Pendekatan Pictorial Riddle Jenis Video Terhadap Hasil Belajar Siswa Dalam Pembelajaran Inkuiri Pada Materi Gelombang Terinegrasi Bencana Tsunami. Jurnal Pillar Of Physics Education, 1(1), 17-22.

Sahayu, S.S., Jampel, N., \& Jayanta, I.N.L. 2018. Pengaruh Model Pembelajaran Probing Prompting berbantuan Media Sederhana Terhadap Hasil Belajar IPA. Jurnal Ilmiah Sekolah Dasar 2(3), 321328.

Septiana, I.S., Harjono, A., \& Hikmawati. 2018. Pengaruh Model Learning Cycle 5E Berbasis Eksperimen Terhadap Kemampuan Berpikir Kritis Fisika Peserta Didik Kelas XI SMAN 1 Gerung. Jurnal Pendidikan Fisika dan Teknologi vol 4(1), 7-15.

Warsita, B. 2008. Teknologi Pembelajaran Landasan dan Aplikasinya. Jakarta: Rineka Cipta. 